\title{
Quality of machined surfaces and specific cutting energy in wood of two African mahogany species
}

\section{Qualidade de superfícies usinadas e energia específica de corte em madeira de duas espécies de mogno Africano}

\author{
Anna Carolina de Almeida Andrade ${ }^{1}$, José Reinaldo Moreira da Silva ${ }^{2}$, \\ Jordão Cabral Moulin² ${ }^{2}$ Mônica Bezerra de Oliveira ${ }^{2}$, Milene Teixeira de Souza ${ }^{2}$ e \\ Lidiane Costa Lima ${ }^{2}$
}

\begin{abstract}
RESUMO
A escassez de informações sobre as características das madeiras de mogno africano e de sua trabalhabilidade limitam sua utilização e introdução no mercado madeireiro. Os objetivos foram avaliar a qualidade da superfície usinada e comparar o consumo de energia específica de corte entre as espécies das madeiras de Khaya ivorensis e Khaya senegalensis com diferentes padrões de usinagem. Para avaliar a qualidade da superfície usinada, foi utilizada uma desempenadeira com rotações de 2400, 3600 e 4000 min $^{-1}$ e velocidade de avanço de 6 e $15 \mathrm{~m}^{*} \mathrm{~min}^{-1}$. A qualidade da superfície foi avaliada por meio do avanço por dente (fz), avaliação visual e rugosidade. Cortes longitudinais e transversais foram realizados por serra circular com rotações de 2500,3000 e 3500 min $^{-1}$ para obtenção da energia de corte específica, por meio de um inversor de frequência. A espécie $K$. senegalensis apresentou consumo de energia de corte $10 \%$ superior a K. ivorensis, já no corte transversal houve maior consumo de $36 \%$ da $K$. senegalensis. Pela qualificação visual as melhores superfícies usinadas foram provenientes da velocidade de avanço de $6 \mathrm{~m}^{*} \mathrm{~min}^{-1}$. A rugosidade não variou em função dos diferentes parâmetros de usinagem e nem entre as duas espécies.
\end{abstract}

Palavras-chave: Madeiras alternativas, energia específica de corte, processamento mecânico, qualificação, rugosímetro.

\begin{abstract}
The scarcity of information on the characteristics and workability of African mahogany wood limits its use and placement on the timber market. The objectives of this study were to assess the quality of the machined surface and compare the consumption of specific cutting energy between the wood species Khaya ivorensis and Khaya senegalensis, with different machining patterns. A trowel was used to assess the quality of the machined surface, with rotations of 2400, 3600 and $4000 \mathrm{~min}^{-1}$, and feeding rates of 6 and $15 \mathrm{~m}^{*} \mathrm{~min}^{-1}$. Surface quality was evaluated by feeding per tooth ( $\mathrm{fz}$ ), visual assessment and roughness. Longitudinal and cross sections were made by a circular saw with rotations of 2500,3000 and $3500 \mathrm{~min}^{-1}$, for the obtention of the specific cutting energy by a frequency inverter. The species $K$. senegalensis had a cutting energy consumption $10 \%$ higher than $K$. ivorensis and, in the cross section, there was a higher consumption (36\%) by $K$. senegalensis. By the visual assessment, the best machined surfaces were obtained with a feeding rate of $6 \mathrm{~m}^{*} \mathrm{~min}^{-1}$. Roughness did not range as a function of different machining parameters or between the two species.
\end{abstract}

Keywords: Alternative woods, specific cutting energy, mechanical processing, qualification, roughness drag.

\section{INTRODUCTION}

The wood generated in planted forests, for example, African mahogany, has gained ground, mainly in the furniture industry and in sawmills. The use of alternative woods is an option that contributes to the protection of native forests, besides reducing the deficit of raw material used in the solid wood industry.

Popularly known as African mahogany, the species was introduced in Brazil in order to replace Brazilian mahogany (Swietenia macrophylla King), which has low to medium shrinkage and good resistance to static strength and compression (MACHADO et al., 2003). Another important factor

1. Centro de Ciências Aplicadas, Universidade Federal de Sergipe - UFS. São Cristovão / SE, Brasil. E-mail: carol bertges@hotmail.com

2. Departamento de Ciências Florestais, Universidade Federal de Lavras - UFLA. Lavras / MG, Brasil.

Sci. For., Piracicaba, v. 46, n. 120, p. 532-539, dez. 2018 DOI: dx.doi.org/10.18671/scifor.v46n120.02 
is the resistance of African mahogany to the major pest (Hypsiphyla grandella (Zeller)) of Brazilian mahogany.

In addition, the use of African mahogany gained ground in the Brazilian timber market, due to the beauty of its wood, high growth rates, seedling production and good technological features (WIEMANN, 2010). However, there are few studies that address these characteristics, such as appropriate machining parameters for satisfactory surface quality and the measurement of energy consumed by these processes.

Since wood is a heterogeneous and anisotropic material, it has different physical/mechanical properties in the transverse, radial and tangential planes, and can be machined in different ways, as a function of direction and sense of the attack between the cutting tool and its fiber. Leitz (2001) stated that it is possible to work the wood longitudinally, transversely and on top, each having its own peculiarities. The specific cutting consumption may range as a function of the cutting direction, as well as intrinsic characteristics of wood, machining parameters and tool sharpening quality.

Regarding machined wood, product qualification occurs by surface analysis and quality setting elements. Silva et al. (2009) showed that there are two research strands that conceptualize machining quality: the first appraises quality only by normative machining values, by calculating the feeding per tooth (fz) or the depth of the cycloid arc; not only does the second strand consider the above-stated parameters, but also the presence of surface flaws, which are generated in function of wood structure, by the presence of different types of cells, their different sizes and orientations.

Due to the importance of mahogany in Brazil and the influence of machining parameters on the quality of the machined timber surface and specific cutting consumption, the objective of this study was to assess the quality of the machined surface and the specific cutting energy consumption of woods of Khaya ivorensis A. Chev and Khaya senegalensis Desr (A. Juss), with different machining patterns.

\section{MATERIAL AND METHODS}

\section{Quality of the machined surface}

In this study, 44 specimens of two 11-year-old species of African mahogany, K. ivorensis and K. senegalensis, were used, with dimensions of $600 \times 140 \times 30 \mathrm{~mm}(\mathrm{~L} \times \mathrm{W} \times \mathrm{T})$, from a commercial plantation in the State of Pará/Brazil.

Planation was performed using a plane trowel in discordant direction, with a 105.0-mm diameter printhead, containing three new knives and exhaust system coupled to the plane. The rotations of the shaft tool holder were 2400, 3600 and $4000 \mathrm{~min}^{-1}$.

A mechanical feeder coupled to a frequency inverter ( $\mathrm{W}-10)$ was used, providing constant feeding rates during planing. Feeding rates were fixed at 6 and $15 \mathrm{~m}^{*} \mathrm{~min}^{-1}$.

A drawing of the specimens was made, as described by Silva et al. (2005), to avoid the influence of cutting edge wear on the quality of planations between the different treatments.

Prior to the assessment of the planed surface, the specimens were transported to a climate chamber with controlled temperature and humidity $\left[\mathrm{T}=(20 \pm 2)^{\circ} \mathrm{C}\right.$ and $\left.\mathrm{RH}=(60 \pm 5) \%\right]$.

After climatisation, the specimens were subjected to random markings of four reading points, with $30 \mathrm{~mm}$ each. High resolution digital images (14.2 megapixels) of these four points were then obtained. Readings were taken to check the number of marks per linear inch (ridges), using the images. From this data, feeding per tooth was obtained.

Based on norm ASTM D1666-11 (ASTM, 2011), that classify the machined surfaces from one to five according to the presence and intensity of pullout and shivering, visual qualification of the woods was performed. In order to reduce the subjectivity of the assessments, they were performed by three examiners according to Silva (2002) methodology, in which the scores were compared in pairs and then with the score of the three evaluators together. Therefore, it was possible to reach a consensus on the final score of each specimen.

Four readings were taken with a roughness drag, at the same locations in which the feeding per tooth was determined. The measured roughness parameter was "Ra", according to a study conducted by Braga (2011).

For the qualification of the machined surfaces based on the roughness parameter "Ra", statistical analyses, using analysis of variance (ANOVA), were carried out at 5\% significance; the factorial test 
Andrade et al. - Quality of machined surfaces and specific cutting energy in

wood of two African mahogany species

between species $\mathrm{x}$ feeding rate $\mathrm{x}$ rotations per minute was then performed and, for the interaction between factors, the Scott-Knott test at 95\% probability was conducted.

\section{Specific cutting energy}

11 specimens of varying length and width were used, with a thickness of $30 \mathrm{~mm}$, in which longitudinal and cross sections were made, representing sections of $90^{\circ}-0^{\circ}$ and $0^{\circ}-90^{\circ}$, respectively. These sections were made by a circular saw in the Wood Machining Laboratory (DCF/UFLA).

The rotations of the shaft tool holder were 2500, 3000 and $3500 \mathrm{~min}^{-1}$. A $300 \mathrm{~mm}$ saw disk with 48 teeth (5.0 mm thick), was used.

The measurement of specific cutting energy was determined for longitudinal and cross sections. Using a frequency inverter (W-08) coupled to the shaft tool holder engine, it was possible to monitor longitudinal and cross sections. Equations 1, 2 and 3 were used to monitor specific cutting consumption in each treatment.

$$
\text { Power }=\frac{T_{m e c} \times n \times 0.0014 \times 736}{1000}
$$

Where:

Power $=$ cutting power $(\mathrm{kw})$;

Tmec $=$ mechanical engine torque $(\mathrm{kgf} * \mathrm{~m})$;

$\mathrm{n}=\operatorname{rotation}\left(\mathrm{min}^{-1}\right)$.

$$
E=\left(\frac{\text { Power } \times C}{V_{f}}\right) \times 60
$$

Where:

$\mathrm{E}=$ energy (kj);

Power $=$ cutting power $(\mathrm{kw})$;

$\mathrm{C}=$ cutting length $(\mathrm{m})$;

$V_{f}=$ feeding rate $\left(\mathrm{m}^{*} \mathrm{~min}^{-1}\right)$

$$
E s=\frac{E}{c \times e \times K}
$$

Where:

Es = specific energy $\left(\mathrm{kj}^{*} \mathrm{~cm}^{-3}\right)$;

$\mathrm{E}=$ energy $(\mathrm{kj})$;

$\mathrm{c}=$ piece length $(\mathrm{cm})$;

$\mathrm{e}=$ piece thickness $(\mathrm{cm})$;

$\mathrm{K}=$ tool tooth thickness $(\mathrm{cm})$.

For specific cutting energy, statistical analysis were carried out by analysis of variance (ANOVA) at $5 \%$ significance. The factorial test was used to verify the interaction between species $\mathrm{x}$ rotations per minute and, for the interaction between factors, the Scott-Knott test at 5\% probability was used.

\section{RESULTS AND DISCUSSION}

\section{Quality of the machined surface}

The mean values of calculated $\left(\mathrm{fz}_{\text {calculated }}\right)$ and measured $\left(\mathrm{fz}_{\text {measured }}\right)$ feeding per tooth for three rotations and two feeding rates are visualized in Table 1 . The number of active teeth was considered equal to 1 for the calculation of feeding per tooth, since the plane trowel used does not have a hydrocentering tool system and correction after its fixation which, according to Silva (2002), is what ensures that all teeth are active.

According to the classification of Senai (1995), the finishing obtained for both rotations at a feeding rate of $6 \mathrm{~m}^{*} \mathrm{~min}^{-1}$ was considered median, while, at a feeding rate of $15 \mathrm{~m}^{*} \mathrm{~min}^{-1}$, finishing quality was considered crude. Therefore, it can be inferred that, by increasing feeding rate, quality is reduced and, when rotation increases, the quality of the machined surface is improved. According to Andrade (2015) and Silva et al. (2009) the same behavior was observed in Eucalyptus spp. of 32 and 37 years old, respectively, proving that the behavior remains with age. This knowledge about the machining 
Table 1. Average feeding per tooth values, measured and calculated, for different rotations and feeding rates.

Tabela 1. Valores médios de avanço por dente calculado e medido para diferentes rotações e velocidades de avanço.

\begin{tabular}{|c|c|c|c|c|}
\hline \multirow{2}{*}{ Rotation (min-1) } & \multirow{2}{*}{ Feeding rate $\left(\mathrm{m}^{*} \mathrm{~min}^{-1}\right)$} & \multicolumn{2}{|c|}{ Feeding per tooth (mm) } & \multirow{2}{*}{$\begin{array}{c}\text { Difference }(\mathrm{mm}) \\
\text { calculated } \mathrm{f}_{\mathrm{z}}-\text { measured } \mathrm{f}_{\mathrm{z}}\end{array}$} \\
\hline & & calculated $\mathrm{f}_{\mathrm{z}}$ & measured $f_{z}$ & \\
\hline 2400 & 6 & 2.5 & 1.9 & 0.6 \\
\hline 2400 & 15 & 6.3 & 7.6 & -1.4 \\
\hline 3600 & 6 & 1.7 & 1.5 & 0.2 \\
\hline 3600 & 15 & 4.2 & 6.6 & -2.4 \\
\hline 4000 & 6 & 1.5 & 1.9 & -0.4 \\
\hline 4000 & 15 & 3.8 & 4.3 & -0.5 \\
\hline
\end{tabular}

parameter is important in order to obtain the surfaces that require the lowest rework and the satisfactory quality for its conventional use.

The measured feeding per tooth was always higher than the calculated, when it was calculated accepting only the number of active teeth as the number of tool teeth, according to the results found by Braga (2011), Guimarães (2005) and Silva et al. (2006). However, these results do not corroborate those found in this study, since the calculated feeding per tooth was higher than the measured feeding per tooth for a feeding rate of $6 \mathrm{~m}^{*} \mathrm{~min}^{-1}$ at 2400 and $3600 \mathrm{~min}^{-1}$.

In table 2 it was presented the percentage values for the species $K$. ivorensis and $K$. senegalensis, classified at different rotations and feeding rates. It was observed that the specimens of both species, obtained worse surface quality scores, when processed at $15 \mathrm{~m}^{*} \mathrm{~min}^{-1}$ and, at the same feeding rate, K. ivorensis had $50 \%$ of the specimens classified as very poor, when machined at a rotation of $3600 \mathrm{~min}^{-1}$; on the other hand, for K. senegalensis, it was found that $100 \%$ of the specimens were classified as very poor.

Table 2. Percentage of $K$. ivorensis and $K$. senegalensis specimens, classified according to ASTM 1666-11(ASTM, 2011), for planations with different rotations and feeding rates.

Tabela 2. Porcentuais de corpos de prova de $K$. ivorensis e $K$. senegalensis classificados segundo a ASTM 1666-11(ASTM, 2011), para os aplainamentos com diferentes rotações e velocidades de avanço.

\begin{tabular}{|c|c|c|c|c|c|c|c|c|c|c|c|}
\hline \multirow{3}{*}{$\frac{\text { Feeding rate }}{\left(\mathrm{m}^{*} \mathrm{~min}^{-1}\right)}$} & \multirow{3}{*}{$\frac{\text { Rotation }}{\left(\mathrm{min}^{-1}\right)}$} & \multicolumn{10}{|c|}{ Percentage of classified specimens (\%) } \\
\hline & & \multicolumn{2}{|c|}{ Score 1} & \multicolumn{2}{|c|}{ Score 2} & \multicolumn{2}{|c|}{ Score 3} & \multicolumn{2}{|c|}{ Score 4} & \multicolumn{2}{|c|}{ Score 5} \\
\hline & & K. I & K. S & K. I & K. S & K. I & K. S & K. I & K. S & K. I & K. S \\
\hline 15 & 2400 & 0 & 0 & 0 & 0 & 0 & 50 & 50 & 0 & 50 & 50 \\
\hline 15 & 3600 & 0 & 0 & 0 & 0 & 0 & 0 & 0 & 50 & 100 & 50 \\
\hline 15 & 4000 & 0 & 0 & 0 & 0 & 0 & 25 & 25 & 75 & 75 & 0 \\
\hline 6 & 2400 & 0 & 0 & 25 & 0 & 50 & 50 & 25 & 50 & 0 & 0 \\
\hline 6 & 3600 & 0 & 25 & 0 & 0 & 50 & 75 & 50 & 0 & 0 & 0 \\
\hline 6 & 4000 & 0 & 0 & 0 & 50 & 75 & 50 & 25 & 0 & 0 & 0 \\
\hline
\end{tabular}

K.I = Khaya ivorensis; K.S = Khaya senegalensis

Silva et al. (2005) evaluated the straightening quality of Eucalyptus grandis wood, and observed that the average score was 3, similar to the result obtained by Braga (2011) for Coffea arabica wood. These results corroborate those found for the wood species K. senegalensis; however, it did not occur with the wood species $K$. ivorensis, to which most of the specimens had a score equal to 5 , with a surface qualified as very poor. The K. ivorensis characteristic coarse interlocked grain can be related to the poor quality of its surface, since this type of grain difficult the machining process (VIDAURRE et al., 2017).

The analysis of variance for the roughness parameter "Ra" obtained by the roughness analysis using a roughness drag is found in Table 3. The quality measurement of the machined surface by a roughness drag is suitable and important, as reported by Cademartori et al. (2015). In this study, it was observed that no statistical differences were found between the analyzed treatments, that is, wood feeding rate and the rotation of the tool did not influence wood roughness.

In studies conducted by Braga (2008) and Silva et al. (2006), it is possible to observe that lower feeding rates and higher rotations provided surface roughness with lower values and, therefore, with a better quality. 
Andrade et al. - Quality of machined surfaces and specific cutting energy in

wood of two African mahogany species

Table 3. Summary of the analysis of variance for the roughness parameter "Ra" during straightening.

Tabela 3. Resumo da análise de variância para o parâmetro de rugosidade "Ra" na operação de desempeno.

\begin{tabular}{ccc}
\hline Variation source & Degree of freedom & Mean square \\
\hline Species (Esp) & 1 & $0.011051^{\mathrm{ns}}$ \\
Feeding rate (Va) & 1 & $0.012834^{\mathrm{ns}}$ \\
Rotations (Rot) & 2 & $0.358404^{\mathrm{ns}}$ \\
Esp*Va $^{*}$ & 1 & $1.295026^{\mathrm{ns}}$ \\
Esp*Rot $^{*}$ & 2 & $1.725454^{\mathrm{ns}}$ \\
Va*Rot $^{*}$ & 2 & $5.225012^{\mathrm{ns}}$ \\
Esp*Va*Rot & 2 & $0.310129^{\mathrm{ns}}$ \\
Error & 84 & \\
Total & 95 & \\
\hline
\end{tabular}

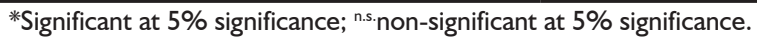

Roughness values did not range between species, since the value for $K$. ivorensis was 3.13, and 3.15 for K. senegalensis. Because the machined surface of African mahogany woods are very similar in quality to those of Brazilian mahogany, they behaved similarly and presented better qualities than those found in the literature. These values are lower than those found by Thoma et al. (2015), who evaluated machined wood surfaces using feeding rates of 5, 7 and $10 \mathrm{~m} . \mathrm{min}^{-1}$ and rotations of 4500 and $6000 \mathrm{~min}^{-1}$ for the species Aleppo pine, European beech, walnut and white oak; roughness values $(\mathrm{Ra})$ were $4.68 ; 5.01 ; 4.89 ; 4.43$ and 5.68 , respectively. These authors report that the difference in roughness values between species may be associated with anatomy and, therefore, it is found that the anatomical characteristics of mahogany may have provided a lower roughness on the wood surface.

\section{Specific cutting energy consumption}

Longitudinal section: The values of specific cutting energy obtained during this process are between 0.141 and $1.078 \mathrm{Kj}^{*} \mathrm{~cm}^{-3}$, with a coefficient of variation equal to $26.71 \%$. This range is consistent with the literature for data obtained for longitudinal section of planks and the high coefficient of variation between the data of specific cutting energy is due to the anatomic singularities of each specimen. However, it is observed that the average value of specific cutting energy was low, which is according to the species, once the African mahogany has easy workability.

The analysis of variance for specific cutting energy in the longitudinal direction of African mahogany wood, for both species and at three rotations, is in Table 4. It is observed that there was a statistical difference between the rotations and African mahogany species at 5\% significance. However, there was no significant difference in the interaction between the mentioned variation sources. Although there was no significant difference for the interaction between rotations and species of African mahogany, at $5 \%$ of significance, observing the generated data, it was verified that $K$. senegalensis presented higher specific energy mean values than those of $K$. ivorensis only for the rotation of $3000 \mathrm{~min}^{-1}$.

Tabela 4. Resumo da análise de variância da energia específica de corte para o corte longitudinal.

Table 4. Summary of the analysis of variance of specific cutting energy for the longitudinal section.

\begin{tabular}{ccc}
\hline Variation source & Degree of freedom & Mean square \\
\hline Rotation & 2 & $0.581025^{*}$ \\
Species & 1 & $0.137548^{*}$ \\
Rotation $x$ Species & 2 & $0.081462^{\text {n.s. }}$ \\
Error & 139 & 0.031035 \\
TOTAL & 144 & \\
CV $(\%)$ & 26.71 & \\
\hline
\end{tabular}

*Significant at $5 \%$ significance; ${ }^{\text {n.s. }}$ non-significant at $5 \%$ significance.

By multiple comparison of means of specific cutting energy at three rotations (Table 5), it was observed that the specific cutting energy increases with increasing rotations of the shaft tool holder. Therefore, the highest mean consumption of specific cutting energy $\left(0.742149 \mathrm{Kj}^{*} \mathrm{~cm}^{-3}\right)$ was obtained at the highest speed $\left(3500 \mathrm{~min}^{-1}\right)$, differing statistically from the other means. There was an increase of $42.7 \%$ in specific cutting energy from the cutting rotation of $2500 \mathrm{~min}^{-1}$ to $3500 \mathrm{~min}^{-1}$. In practical 
Table 5. Multiple comparison of means of specific cutting energies of the longitudinal section at different rotations and species of African mahogany wood.

Tabela 5. Comparação múltipla das médias das energias específicas de corte do corte longitudinal para as diferentes rotações e espécies de mogno africano.

\begin{tabular}{ccc}
\hline & & Specific cutting energy $\left.\mathbf{~ K j}^{*} \mathbf{c m}^{-3}\right)$ \\
\hline Rotations (min-1) & 2500 & $0.520177 \mathrm{~b}$ \\
& 3000 & $0.566852 \mathrm{~b}$ \\
Species & 3500 & $0.742149 \mathrm{a}$ \\
& K. ivorensis & $0.627660 \mathrm{~b}$ \\
& K. senegalensis & $0.689296 \mathrm{a}$
\end{tabular}

Means followed by at least one same letter do not differ by the Scott-Knott test at $5 \%$ significance.

terms, seeking a better quality of the machined surface and lower specific cutting energy expenditure, it was observed that both rotations of 2500 and $3000 \mathrm{~m}^{-1}$ present the less specific cutting energy, then the indication is to use the rotation of $3000 \mathrm{~m}^{-1}$, once higher rotations generate higher speeds of advance which consequently gives better surface quality during the wood machining.

By multiple comparison of means of specific cutting energy (Table 5), it was observed that the consumption of specific cutting energy was $10 \%$ higher for the mechanical processing of K. senegalensis wood than that reported for $K$. ivorensis wood. The literature presents that the density for K. senegalensis is $0,510 \mathrm{~g}^{*} \mathrm{~cm}^{-3}$ and for $K$. ivorensis is $0,487 \mathrm{~g}^{*} \mathrm{~cm}^{-3}$, which can explain the more energy required in the cut for the first one, once the denser the material, the greater the effort required during cutting and the greater the specific cutting energy consumed (REZENDE et al., 2012).

Cross section: Specific cutting energy values obtained during the cross-section process are between 0.104 and $1.204 \mathrm{Kj}^{*} \mathrm{~cm}^{-3}$, with a coefficient of variation equal to $36.92 \%$. In relation to the longitudinal cut, the cross-section cut presented higher values of specific cutting energy, since the longitudinal cut is facilitated by the splitting forces presented, requiring less cutting efforts.

The analysis of variance of specific energy values in the cross section of the wood from two African mahogany species at three rotations is visualized in Table 6. It was observed that there was a significant difference only between species. Although there was no significant difference in the interaction of rotations and species, it was found that the highest specific cutting energy consumption occurred for both African mahogany species at a rotation of $2500 \mathrm{~min}^{-1}$. In practical terms, this means that the intrinsic characteristics of the woods, for example their density and anatomy, were the main factor to influence the specific cutting energy.

Table 6. Summary of the analysis of variance of specific cutting energy for the cross section.

Tabela 6. Resumo da análise de variância da energia específica de corte para o corte transversal.

\begin{tabular}{ccc}
\hline Variation source & Degree of freedom & Mean square \\
\hline Rotation & 2 & $0.005111^{\text {n.s.* }}$ \\
Species & 1 & $1.029902^{*}$ \\
Rotation ${ }^{*}$ Species & 2 & $0.044080^{\text {n.s. }}$ \\
Error & 114 & $0.049476^{\text {n.s. }}$ \\
TOTAL & 119 & \\
CV $(\%)$ & 36.92 & \\
\hline
\end{tabular}

*Significant at $5 \%$ significance; n.s.non-significant at $5 \%$ significance.

The average specific cutting consumption of K. senegalensis (0.699861) was significantly higher than that of $K$. ivorensis (0.514345). Therefore, it is observed that K. senegalensis consumes $36 \%$ more energy during its cutting process.

Comparing the specific cutting energy of the longitudinal section with that of the cross section, Leitz (2001) stated that fiber cross section is easier to carry out, requiring a lower cutting energy. However, the machined surface becomes rough, due to the arrangement of wood fibers in relation to the cutting edge. Souza (2009) found a lower cross section consumption in Eucalyptus sp. wood, confirming the results obtained for K. ivorensis wood in the present study, and although for K. senegalensis the specific cutting energy for the longitudinal cut was higher than for cross section cut, values were very similar. 
Andrade et al. - Quality of machined surfaces and specific cutting energy in

wood of two African mahogany species

The knowledge about the specific cutting energy of African mahogany is important to understand the behavior pattern for longitudinal and cross section cuts of these species to indicate, as a function of lower energy consumption, the type of cutting more efficient for each species.

\section{CONCLUSIONS}

In the longitudinal section of both species, the smallest specific energy consumptions were observed at rotations of 2500 and $3000 \mathrm{~min}^{-1}$. The species K. ivorensis showed a lower specific cutting energy consumption than K. senegalensis;

The reduction in feeding rate and increased rotation of the shaft tool holder showed better machined surface qualities for feeding per tooth;

Better surface qualities for both African mahogany species were presented, when machined at a feeding rate of $6 \mathrm{~m}^{*} \mathrm{~min}^{-1}$. The rotation of $2400 \mathrm{~min}^{-1}$ and $3600 \mathrm{~min}^{-1}$ showed the best results in the quality of the machined surface for K. ivorensis and K. senegalensis, respectively;

Surface qualification with the roughness drag was not significantly different for the different machining parameters. The two mahogany species presented the same roughness.

\section{REFERENCES}

ASTM - AMERICAN SOCIETY FOR TESTING AND MATERIALS. ASTM D1666 - 11 standard method for conducting machining tests of wood and wood base materials (reapproved 1994). Philaldelphia, 2011. p. 226-245.

ANDRADE, A. C. A. Sunset laser na análise de deifeitos em madeiras usinadas. 2015. 41 p. Dissertação (Mestrado em Ciência e Tecnologia da Madeira) - Universidade Federal de Lavras, Lavras, 2015.

BRAGA, P. P. C. Estabelecimento de padrões de usinagem e qualidade de acabamento em madeira de Coffeaarabica. 2011. 57 p. Dissertação (Mestrado em Tecnologia da Madeira) - Universidade Federal de Lavras, Lavras, 2011.

BRAGA, P. P. C. Análise da superfície usinada de madeiras por meio de rugosímetro de arraste. 2008. 47 p. Monografia (Graduação em Engenharia Florestal) - Universidade Federal de Lavras, Lavras, 2008

CADEMARTORI, P. H. G.; MISSIO, A. L.; MATTOS, B. D.; GATTO, D. A.; MAGALHÃES, W. L. E.; LIMA, E. A. Roughness and color evaluation of wood polymer composites filled by household waste of mate-tea. Maderas. Ciencia y tecnologia, Concepcion, v. 17, n. 3, p. 457-468, 2015.

GUIMARÃES, M. A. M. Avaliação de superfícies usinadas em madeira de Eucalyptus grandis. 2005. 52 p. Monografia (Graduação em Engenharia Florestal) - Universidade Federal de Lavras, Lavras, 2005.

LEITZ, L. Das leitz lexikon. 3.ed. Unterschneidheim: Übersicht Zahnformen, 2001.

MACHADO, J. S.; CRUZ, H.; NUNES, L. Mitos e factos relacionados com o desempenho de elementos de madeira em edifícios. In: ENCONTRO SOBRE CONSERVAÇÃo E REABILITAÇÃO DE EDIFÍCIOS. 3., 2003, Lisboa. Anais... Lisboa: ECRB, 10 p.

REZENDE, R. N.; LIMA, J. T.; SILVA, J. R. M.; MONTEIRO, T. C.; PAULA, L. E. R. Avaliação das propriedades físicas e mecânicas das madeiras de Khaya ivorensis e Khaya senegalensis (mogno africano). In: ENCONTRO BRASILEIRO EM MADEIRA E EM ESTRUTURAS DE MADEIRA. 13., 2012, Vitória. Anais... Vitória: IBRAMEM, 2012.

SENAI - SERVIÇO NACIONAL DE APRENDIZAGEM INDUSTRIAL. Acabador de móveis. Ubá: CFP/JAGS, 1995. $29 \mathrm{p}$.

SILVA, J. R. M. Relações da usinabilidade e aderência do verniz com as propriedades fundamentais do Eucalyptus grandis Hill ex. Maiden. 2002. 179 p. Tese (Doutorado em Ciências Florestais) - Universidade Federal do Paraná, Curitiba.

SILVA, J. R. M.; MARTINS, M.; OLIVEIRA, G. M. V.; BRAGA, P. P. C. Parâmetros de Qualidade da usinagem para determinação dos diferentes usos da madeira de Eucalyptus. Cerne, Lavras, v. 15, n. 1, p. 75-83, 2009. 
SILVA, J. R. M.; LIMA, J. T.; BRAGA, P. P. C.; TRUGILHO, P. F. A utilização de rugosímetro na qualificação de superfícies usinadas em madeiras de Eucalyptus sp. In: ENCONTRO BRASILEIRO EM MADEIRAS E EM ESTRUTURAS DE MADEIRA, 10. 2006. Anais...São Pedro: EBRAMEN, 2006.

SILVA, J. R. M.; MUNIZ, G. I. B.; LIMA, J. T.; BONDUELLE, A. F. Influência da morfologia das fibras na usinabilidade da madeira de Eucalyptus grandis Hill ex. Maiden. Revista Árvore, Viçosa, v. 29, n. 3, p. 479-487, 2005.

SOUZA, E. M. Influência dos parâmetros de usinagem da madeira de Eucalyptus sp. no consumo de energia específica de corte em serra circular. 2009. 50 p. Dissertação (Mestrado em Ciência e Tecnologia de Madeira) - Universidade Federal de Lavras, Lavras, 2009.

THOMA, H.; PERI, L.; LATO, E. Evaluation of wood surface roughness depending on species characteristics. Maderas. Ciencia y tecnologia, Concepcion, v. 17, n. 2, p. 285-292, 2015.

VIDAURRE, G. B.; SILVA, J. G. M.; CASTRO, M.; COELHO, J. C. F.; BRITO, A. S.; MOULIN, J. I. Relação da grã com algumas variáveis do crescimento e propriedades da madeira de Khaya ivorensis. Scientia Forestalis, v. 45, n. 114, p. 249-259, 2017.

WIEMANN, M. C. Characteristics and availability of commercially important woods. In: Forest Products Laboratory-FPL. Wood Handbook: wood as an engineering material. Madison: FPL/USDA, 2010. Cap. 2, p. 16-60.

Recebido em: 06/02/2017

Aceito em: 27/03/2018 